\title{
Feasibility Analysis of Breeding Sheep Garut
}

\author{
Ina Ratnasari, Dian Hakip Nurdiansyah \\ Universitas Singaperbangsa Karawang \\ Economics and Business Faculty \\ dianhakip110@gmail.com
}

\begin{abstract}
Karawang District as one of the agricultural areas in West Java province have large farms, allowing one to open a sheep breeding business. The availability of sufficient land to provide food make Karawang area deserves to be one of the region for breeding sheep or goats. This study aims to examine the feasibility of breeding sheep garut livestock group on Al-Barokah that exist in Karawang District. This research was conducted by using the method Participatory Action Research (PAR). Data were analyzed qualitatively and quantitatively. The results of this research concluded that aspects of nonfinancial which consist of market aspect, marketing aspect, technical aspect and operation, management aspect and the environmental aspect, breeding sheep Garut is feasible. Whereas the financial aspects, factors taken into consideration are investment value, revenue analysis, payback period, net present value, index profitability, and internal rate of return. Garut sheep breeding investment value for 60 broodstocks amount of Rp. 337.665.000. Revenue analysis annual average is $\mathrm{Rp} 380.900 .000$ with total average cost per year of Rp. 77.267.960. The payback period value $=1$ year 10 months 3 days. The net present value for economical age of positive project is Rp. 406.513.831. Profitability index value $>1$ is 2.20. Then the value of IRR is greater than the value of the interest rate $(53.6 \%>14 \%)$. Therefore, based on the financial aspects of breeding sheep Garut is feasible to be implemented. The conclusion of Al-Barokah livestock group is feasible to do the breeding business of sheep garut because based on the financial and non-financial aspects, the business is feasible to be implemented.
\end{abstract}

Keyword: Business Feasibility Study; Breeding Sheep; Financial Management

\section{INTRODUCTION}

Indonesia is one of the countries that have the nutritional needs especially animal are high enough.. The faster population growth rate also resulted in a number of nutritional needs also increase. Public awareness about nutrition now has started to increase. In addition, the increased revenue also participated and lead to increase awareness of the importance of nutritional origin of animal protein, public awareness of the importance of lamb to increase the intelligence of the toddler, including intervention by the Government to open and expand market opportunities in the country, will be increasingly open market sheep and goats in the country.
The need for meat consumption is increasing every year. Along with the addition of a population in Indonesia was, hence the need for meat also increases. The current meat consumption in Indonesia is still dominated by beef. Currently, an estimated production capacity of beef in the country is able recently to contribute around (70-75)\% against a national need, whereas PSDS 2010 proclaimed by Governments demands the role of beef production in the country to make a contribution amount of (90-95)\%. Until 2013 there is the shortage of beef supply in the market, it also will impose on increasing the consumption of the meat of sheep and goats, even for sheep and goat meat, there is not a specific market share. The current market share of sheep and goat meat in Indonesia is very low or only by $5 \%, 56 \%$ poultry, $23 \%$ beef, $13 \%$ pork, $3 \%$ other meat. [1]

Karawang District as one of the agricultural areas in West Java province have large farms, allowing one to open a sheep farm. The availability of sufficient land to provide food make Karawang area deserves to be one of the region for breeding sheep or goats. Goats are animals that have a high tolerance to different types of forage and have good adaptability to various environments. Development goats have good prospects as well as to meet the needs of meat in the country, goats also have the opportunity as an export commodity.

Sekarwangi village is a village in district Rawamerta, Karawang. The village Sekarwangi some of its territory is an agricultural area and settlements with area: 288600 ha. A total of $38 \%$ of the population of the village of Sekarwangi farmers. Therefore, to increase household income, then some people there who keep livestock were productive enough power plays. The availability of sufficient feed mainly grass Sekarwangi make the areas it is possible to be a breeding area especially goats and domba.

There are two types of options when it will run a goat farm that is fattening and breeding. When compared with fattening, goat breeding is arguably relatively more relaxed. In fattening goats, farmers work to achieve maximum weight in order to get the maximum benefit. Breeders interact with many factors including: seeds, forage quality, adequate water, power board cold, enclosure ideal, the timing of feeding and proper vitamins, medicines as prescribed and analysis, all of which leads to weight gain and weight again. In breeding maintenance could use intensive and semi- 
intensive maintenance. Breeding sheep which require minimal frequency of anthelmintic treatment to maintain acceptable health and productivity while grazing under condi- tions of natural nematode challenge is 1 of several options which may assist in managing anthelmintic resistance and in meeting consumer demands to minimise drug usage in the livestock farming industry. However, the most appropriate breeding strategy to achieve this goal is as yet unclear [2].

Al Barokah livestock groups have the plans to do a business of breeding sheep. Observing the fairly high marketing potential, broodstock breeding result not only will be marketed in the area of Karawang and surrounding, but also will it be marketed to the other areas such as purwakarta, bekasi and subang. Before development of breeding sheep implemented, first there should be research on whether the business will be initiated is feasible to be implemented or not. For this reason the author together a group preparing a feasibility analysis. Feasibility analysis was conducted on the financial aspect and non financial aspects, covering aspects of the market, technical, and management are intertwined with each other in determining the success of the business to be implemented.

This research was conducted using the method of Participatory Action Research or Participatory Action Research (PAR). In Farmers Participatory Action Research Al-Barokah not mere objects of research but as the main actors together with researchers in the process of preparation of feasibility analysis. Through this study, it is expected to improve the ability of the community to identify any existing problems and find solutions to settle the problem. By doing so, the goat raising in Al-Barokah Farmers Group is expected to further develop.

\section{LITERATURE REVIEW AND FRAMEWORK OF THOUGHT}

Decision-making for investment is a very risky decision. The investment itself could in the form of investment business or investment of social activities either the existing business development or creating a new business. [3]

Explained that investment activity is the act of removing a number of funds in a certain quantity in order to gain an advantage or greater benefit in the future, either material or non-material benefit.

Business and investment feasibility analysis is needed in order to minimize risk and ensure the magnitude of the benefit that would be obtained, in accordance with what we expect, optimally. [4]

Stated that the business feasibility study is an examination of the business plan that not only analyzes the feasibility of the business to be built, but also the moment of operational on a regular basis in the framework of the achievement of the maximum profit for an unspecified time, for example, the plans of the launch of a new product.

Business aspects that should be examined in the business feasibility study are aspects of the market, aspects of the internal company and environmental aspects as seen in the figure 1 .

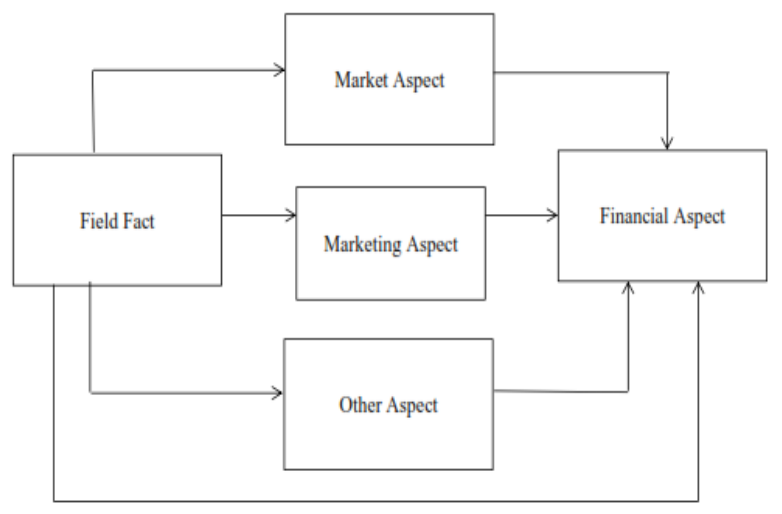

Fig. 1. The information flow between aspects in the business feasibility study

The aspect of the market analyzed in the study of the feasibility of business include analyzing market potential, the intensity of competition, as well as the market share that can be achieved by a business venture or investment [5]. While the marketing aspects of feasibility Analysis is:

a. The determination of segment, target, and the product position on the market.

b. The study to find out the potential consumer, as a matter of attitude, behavior, as well as their decisions on products.

c. Determining the strategy, policy, and marketing programs to be implemented [6].

The technical aspects in the study of Feasibility of discussing the things that are directly related to the business operations, such as production capacity, technologies used, scale of production, the production process, the location, layout, scheduling, as well as setting the level of inventory [7]. Management aspects study the things related to the management plan and the implementation of the business that will run [8]

Environmental aspects analyzed the suitability of the surrounding environment (both the operational environment, the near environment and far environment) with a business idea that will run. In addition to the other factors which should be examined on the environmental aspects of sociocultural environmental factors are. Social and cultural factors have a major impact on all of the products, services, markets and customers [9].

Social factors that affect a company's beliefs, values, attitudes, opinions, and lifestyles of the people in the external environment of the company, which develops the influence of culture, ecology, demography, religion, education, and ethnic.[10]

The financial aspect in general is an aspect that is most final compiled in a business feasibility study preparation. This is because a study in finance requires information relating to previous aspects. A profit-oriented and not 
oriented to profit business should remain mindful of the financial aspect prior to running the business. Profit-oriented businesses will decide the business idea of running a profitable financially [11].

On the financial aspect in the analysis of the return on investment that is embedded with the feasibility analysis based on some investments, such as Payback Period (PP), Net Present Value (NPV), Profitability index (PI), Internal Rate Of Return (IRR) and the Average Rate Of Return (ARR).[12]

Through participatory learning it is found a problem where for the next few years Al-Barokah farmer group will conduct the business of breeding sheep garut. Therefore it needs to be done a learning on the preparation of a business feasibility analysis. The purpose of this business feasibility analysis is to find out whether the breeding sheep garut is feasible or not to be run. When feasible then the breeding sheep garut is implemented and if not then the breeding sheep garut is unenforceable.

Research about a feasibility study have been in the world this is a result from the studied about Goat Population in the World Table 2.1 Countries with the Highest Goat Population Country Population (Head) China 149.376.747 India 125.732.000 Pakistan 56.742.000 Bangladesh 56.400.000 Nigeria 53.800.400 Sudan 43.100.000 Iran 25.300.000 Ethiopia 21.884.222 Mongolia 19.969.400 Indonesia 15.805.900 Source: FAOSTAT 2011 Indonesia is in the top ten goat population in the world [13].

\section{RESEARCH METHODOLOGY}

The research was conducted using a Participatory Action Research (PAR). In Participatory Action Research AlBarokah farmer group is not made as the research object but as a major offender along with researchers in conducting the process of preparing an analysis of the business feasibility. Through this research it is expected to enhance the community's ability to identify each problem and find a solution to the problem and finish.

In general the process of Participatory Action Research is a process which occurs over and over again including processes such as planning, action and reflection. This process begins with observation to identify any of the problems that exist. The observation result was later appointed as an important factor to consider in planning, followed by action/real action to achieve a goal, and then conducted a reflection/evaluation to be used as learning materials in the further planning and action until the occurrence of a change in the future. This process happens repeatedly.

The last process in this research is jointly with the community to construct a business feasibility analysis to be able to measure the feasibility or infeasibility of the business which was accompanied to the process of further development. In addition, it is useful to attract investors willing to fund the livestock business of goat at Al-Barokah farmer group. The technique used is to use interview techniques individually and in groups.
The data were analyzed qualitatively and quantitatively. Qualitative (descriptive) Analysis is used to find out aspects of the marketing, technical, and management. The marketing aspect includes the target market, market opportunities, and marketing mixture. While the technical aspects include stages of the production process, production facilities and raw materials used for the production process. Aspects of management include the permissions, ownership, organizational structure, job description, and systems of compensation. Qualitative analysis is done on participatory with community/farmers. While the financial aspects were analyzed quantitatively using an analysis of revenues and investment criteria analysis.

\section{RESULTS AND DISCUSSION}

Sheep Garut has a multi user potential market. This makes the Garut Sheep farm animals deserve to be developed as an option in the livestock business sector. The first biggest potential market is the Garut Sheep farm animals to meet annual worship of sacrifice. Needs of sheep and goat for sacrifice 2013 increased 10-15\% from the year 2012 with an increased price per animal average Rp. 400.000 - Rp. 500.000. Then following the daily meat consumption needs both for household, restaurant and sate stall. Next is the need for aqiqah. In Indonesia there are 3.5 million baby births in one year. If half wants to be aqiqah, demand for goat and sheep reaching 2 million animals per year for the purposes of aqiqah only. Last is the hobbyist always looking for breeding excellent male sheep garut.

If you see the above data then it can be concluded the business opportunities to do breeding sheep garut is still widely open. The reason is because the demand for lamb each year continues to grow in line with the population that continues to increase. The market share for seedlings of sheep Garut also consists of many different types of businesses, among others, livestock, restaurant or bistro, sacrifice market, aqiqah market, and pemidangan market. The more expensive Garut sheep seedling price makes breeding sheep Garut be the business opportunities which have advantages compared to the other sheep breeding. Therefore the business of breeding sheep that will be carried out by the Al-Barokah cattle group in Cilele sub-village, Sekarwangi village, Rawamerta district is feasible to be implemented.

On the marketing aspects, Al-Barokah cattle group can continue doing the business of breeding sheep garut because the extensive marketing area and the opportunity for the activities of the breeding as the activity of fattening and breeding is still wide open both domestically and abroad. Then standardization of products also has been available and the price as well as media promotion have also been available.

Seen from the technical and technology aspects, AlBarokah cattle group can resume plans to make livestock engaged in breeding sheep garut because the production stage that does not take a long time, then the facility is not too complicated, the technology used is only using traditional ways and then the maintenance way is not too complicated with a background of members who have 
become accustomed to doing sheep livestock activities, AlBarokah cattle group is not going to have trouble. Moreover seeing their background formed the group because they have the same hobby namely breeding sheep. They also have enough knowledge about health maintenance method of sheep because they often attended training organized by the Department of agriculture, livestock and fisheries. They have been able to make their own supplementary feed with the composition of fine bran, teri flour, hay, coconut husks and white cement.

Whereas, in the aspect of management, Al-Barokah cattle group is feasible for doing business of breeding sheep garut because labor is available and has the skills for raising and managing the livestock, has the organizational structure and has the task division systems in the group.

Then on the environmental aspects, the business of the breeding sheep garut is feasible to be implemented because of various supporting factors, among other the business environment that has not yet the availability of specialized livestock of breeding sheep in the Karawang area, the livestock waste that can be used so it is not to pollute the environment and socio-cultural factor support i.e. existence of sacrificial and aqiqah customs supporting for implementation of livestock of breeding sheep garut by AlBarokah cattle group.

In other research the author have a great suggestion there is the writer suggesting that this farm not only focused on the fattening process. In order to make sure that they get the best breed for the fattening process, they start to breeding by themselves. The farm need to find the best breed for goat and sheep fattening so in the future the fattening process could also produce the best goat and sheep meat and ready to infiltrate the international market [14].

If on the non-financial aspects all of the criteria are met so that the businesses can already be declared eligible to continue, then the next aspect to determine acceptable or not for a project proposal is the financial aspect. On the financial aspects, factors taken into consideration are investment value, revenue analysis, payback period, net present value, profitability index, and internal rate of return.

The total investment required for doing the business of breeding sheep garut is Rp. 316.665.000. Revenue analysis per year is average of $\mathrm{Rp} 380.900 .000$ with a total average cost per year of Rp. 77.267.960. The value of the payback period $=1$ year 10 months 3 days. The age of economical investment project is 5 years. Mean value payback period < economical age, then investment proposal is feasible accepted.

The next stage is we calculate time value of money from cash go in the net for age economically by doing the calculation of net present value. The following is the calculation:

TABLE I. Net Present Value

\begin{tabular}{|c|c|c|c|c|c|}
\hline \multirow[t]{2}{*}{ Description } & \multicolumn{5}{|c|}{ Year } \\
\hline & 1 & 2 & 3 & 4 & 5 \\
\hline Proceed & 130.575 .430 & 246.348 .425 & 246.348 .425 & 246.348 .425 & 246.348 .425 \\
\hline$\overline{D F} 55 \%$ & 0,6452 & 0,4162 & 0,2685 & 0,1732 & 0,11118 \\
\hline PV of Proceed & 84.242 .213 & 102.538 .366 & 66.153 .785 & 42.679 .861 & 27535.394 \\
\hline \multicolumn{5}{|c|}{ PV in Lays } & 323.149 .619 \\
\hline \multicolumn{5}{|c|}{ PV out Lays } & 337.665 .000 \\
\hline \multicolumn{5}{|c|}{ NPV } & $(14.515 .381)$ \\
\hline
\end{tabular}

TABLE II. THE RESULT OF PV

\begin{tabular}{|c|c|c|c|c|c|}
\hline \multirow[t]{2}{*}{ Description } & \multicolumn{5}{|c|}{ Year } \\
\hline & 1 & 2 & 3 & 4 & 5 \\
\hline Proceed & 130.575 .30 & 246.348 .45 & 246.340 .425 & 24634845 & 246348.45 \\
\hline DF $1+\%$ & 0.8772 & 0.1162 & $0.67 \mathrm{~V}$ & (15\%)1 & 15194 \\
\hline PV of Proceed & $11+599.851$ & $189 . \$ 7.114$ & 166.278 .170 & 15.568 .44 & 127.94.6\%? \\
\hline \multicolumn{5}{|c|}{ PYin Lays } & $7+4.178831$ \\
\hline \multicolumn{5}{|c|}{ PV out Lays } & 337.66406 \\
\hline \multicolumn{5}{|c|}{ NPV } & 4t6513831 \\
\hline
\end{tabular}

Based on the table above, the value of net present value for economical age of positive project is Rp. 406.513.831. Thus the investment proposals could be accepted. Based on the table above, the net present value economical age of positive project is Rp. 406.513.831. Thus investment proposals could be accepted.

Furthermore after doing the calculation of the time value of money, we compute a comparison between the present value of net cash receipts in the future (proceed) and investment present value (outlays).

Fig 4.1 formula of Profitablity indeks

$$
\begin{aligned}
\text { Profotability Indeks } & =\frac{\text { PV of Benefit }}{\text { PV of Capital Cost }} \\
& =\frac{744.178 .831}{337.665 .000} \\
& =2,20
\end{aligned}
$$

Thus the investment proposal is acceptable because the value of profitability index $>1$ namely amount of 2.20.

The next step in the financial aspects of a business feasibility study is the Internal Rate of Return (IRR). Calculation of the IRR to determine the magnitude of interest rate that equates the present value of the investment with the net result expected for the business running. When we calculate the IRR, then we try doing the calculations on the interest rate which is different until the PV value is negative.

Here is the calculation of the time value of money at a higher interest rate of $55 \%$ :

Thus then the IRR calculation is as follows:

Fig 4.2 formula from IRR

$$
\begin{gathered}
I R R=i_{1}+\frac{N P V_{1}}{N P V_{2}-N P V_{1}}\left(i_{2}-i_{1}\right) \\
I R R=0,14+\frac{406.513 .831}{323.543 .292-744.178 .831}(0,55-0,14) \\
=53,6 \%
\end{gathered}
$$

The value of the IRR is greater than the value of the interest rate $(53.6 \%>14 \%)$ then the investment proposals could be accepted. 


\section{CONCLUSION}

Based on the results of the feasibility study of the business which has been done, then a conclusion can be obtained as follows:

- Based on the assessment of the non-financial aspects that comprise the market aspect, the marketing aspect, technical and technological aspects, aspects of management and HUMAN RESOURCES as well as environmental aspects, then the garut sheep breeding business plan which will be implemented by AlBarokah cattle group deserves to be implemented.

- Based on financial aspects by taking into account the value of the payback period, net present value method, profitability index, and internal rate of return, then the investment then the garut sheep breeding business plan which will be implemented by Al-Barokah cattle group deserves to be implemented.

\section{REFERENCES}

[1] Disnak " Peternakan Domba " 1 january 2015.

[2] Bisset,.S. A., and C. A. Morris, "Feasibility and Implications of Breeding Sheep" , Intornational Journalfor Purusitotogv, Vol. 26, No. 8/9, 1996, p. 857-868.

[3] Mohammad Riyan" konsumsi daging" 12 November 2013.

[4] http://www.tribunnews.com/regional/deddy-mizwar-kampanyekonsumsi-daging-domba-dan-kambing Unpublished.

[5] Rangkuti, Freddy. Studi Kelayakan Bisnis Dan Investasi. Jakarta : PT. Gramedia Pustaka Utama. 2012.

[6] Umar, Husein. Studi Kelayakan Bisnis. Jakarta : PT Gramedia Pustaka Utama. 2003.K. Elissa, "Title of paper if known," unpublished.

[7] Suliyanto. Studi Kelayakan Bisnis. Yogyakarta : Penerbit ANDI. 2010 .

[8] Umar, Husein. Studi Kelayakan Bisnis. Jakarta : PT Gramedia Pustaka Utama. 2003.

[9] S, Eleazar Dodo.. "Analisis Kelayakan Usaha Ternak Kambing Melalui Penelitian Aksi Partisipatif (Studi Kasus : Kelompok Tani Harapan Mekar, Situgede, Bogor Barat, Bogor, Jawa Barat)”. Bogor : Institut Pertanian Bogor. 2007.

[10] Rangkuti, Freddy. Studi Kelayakan Bisnis Dan Investasi. Jakarta : PT. Gramedia Pustaka Utama. 2012.

[11] Suliyanto. Studi Kelayakan Bisnis. Yogyakarta : Penerbit ANDI, 2010.

[12] Irwan, S “Kelayakan Bisnis Lingkungan,” 10 January 2012.

[13] O. Mahgoub, I. K., Overview of the Global Goat Meat Sector. Goat Meat Production and Quality, 2011, p.1-14.

[14] Febrianno Erlangga, "Investment Analysis On Goat And Sheep Fattening Project Based On The New Food Fermentation Farming method ( $3 \mathrm{f}$ method) "the indonesian journal of business administration vol. 1, no. 9, 2012, p. 613-621 